MANABE, S. \& WeThERALD, R.T. (1986). Reduction in summer soil wetness induced by an increase in atmospheric carbon dioxide. Science, 232, pp. 626-8, illustr.

MANABE, S. \& WETHERALD, R.T. (1987). Large-scale changes of soil wetness induced by an increase in atmospheric carbon dioxide. J. Atmos. Sci., 44, pp. 1,211-35, illustr.

Moller, D. (1984). Estimation of the global man-made sulphur emission. Atmos. Environ., 18, pp. 19-27, illustr.

Quinlan, F.T., KaRL, T.R. \& Williams, C.N., jun. (1987). United States Historical Climatology Network (HCN) Serial Temperature and Precipitation Data. NDP-019, Carbon Dioxide Information Analysis Center, Oak Ridge National Laboratory, Oak Ridge, Tennessee, USA: viii + $32 \mathrm{pp}$.

Revelle, R.R. \& WaGgoner, P.E. (1983). Effects of a carbon dioxide-induced climatic change on water supplies in the western United States. Pp. 419-32 in Changing Climate. US National Research Council (Eds), National Academy Press, Washington, DC, USA: xxiii + 496 pp., illustr.

Rind, D., Goldberg, R., Hansen, J., Rosenzweig, C. \& Ruedy, R. (1990). Potential evapotranspiration and the likelihood of future drought. J. Geophys. Res., 95, pp. 9,983-10,004, illustr.

RoTTY, R.M. \& MASTERS, C.D. (1985). Carbon dioxide from fossil fuel combustion: trends, resources, and technological implica- tions. Pp. 63-80 in Atmospheric Carbon Dioxide and the Global Carbon Cycle (Ed. J.R. TRABALKA). US Department of Energy, Washington, DC, USA: xxiii + 315 pp., illustr.

SCHLesinger, M.E. \& Mrtchell, J.F.B. (1987). Climatic model simulations of the equilibrium climate response to increased carbon dioxide. Rev. Geophys., 25, pp. 760-98, illustr.

SCHWARTZ, S.E. (1988). Are global cloud albedo and climate controlled by marine phytoplankton? Nature (London), 336, pp. $441-5$, illustr.

Staubes, R., Georgit, H.-W. \& Ockelmann, G. (1989). Flux of $\mathrm{CO}_{2}$, DMS and CS2 from various soils in Germany. Tellus, 41B, pp. 305-13, illustr.

Vinnikov, K.YA., Croismann, P.YA. \& Lugina, K.M. (1990). Empirical data on contemporary global climate changes (temperature and precipitation). J. Climate, 3, pp. 662-7, illustr.

SHERWOOd B. IDSO

\&

Robert C. Balling, Professor

Laboratory of Climatology

Arizona State University

Tempe

Arizona 85287

USA.

\title{
Air Traffic and Changing Climate
}

\section{Introduction}

Recent studies on climate have produced extremely disquieting findings about the effects on it of air traffic. They have shown that, at altitudes above 9,000 metres, the water vapour emitted from aircraft engines has to be regarded as a pollutant. For it forms additional cirrus icecrystal clouds, which contribute to the rising temperature on Earth. Moreover, a problem that has not been solved, as there are no catalytic converters for jet engines, is the emission at the same time of nitrogen oxides $\left(\mathrm{NO}_{\mathrm{X}}\right)$. Near to the ground, nitrogen oxides raise ozone levels in the atmosphere, while at higher altitudes, the opposite occurs. There, nitrogen oxides help to break down the ozone in the stratosphere, where it forms a shield that protects The Biosphere against the short-wave radiation which is harmful to life. In fact, the consequences of air traffic are very much more serious than would be assumed from their $13 \%$ share of the world's consumption of traffic fuel.

\section{Water Vapour: Harmful to Climate at High Altitudes}

Water vapour in airplane exhaust is harmful at high altitudes (Grassl, 1989), although not at the lower levels which are the ones mainly involved in weather processes. The latter take place mostly below 4,000 metres, although during thunderstorms the air can circulate to about 7,000 metres (or in the tropics even up to 16,000 metres). Above this the air is relatively calm, and so the water vapour in the exhaust of aeroplanes remains there for a relatively long time.

Above 9,000 metres, the air is mostly very cold (between $-40^{\circ} \mathrm{C}$ and $-80^{\circ} \mathrm{C}$ ). Only extremely small amounts of water vapour can therefore be absorbed so high up (a few parts per million by volume). The water vapour emitted from aircraft engines (on average $1.25 \mathrm{~kg}$ water per $\mathrm{kg}$ of kerosene fuel) therefore forms artificial ice-crystal clouds that are known as cirrus clouds. If one assumes that, world-wide, about $40 \%$ (Kavanaugh, 1988) of kerosene is burnt between 9,000 and 13,000 metres, then in 1988 around 80 million metric tons of water entered these endangered layers of the atmosphere!

Only a small part of the cirrus clouds formed by aircraft is visible as condensation trails. Sunlight can pass through them almost completely, although heat from the ground is kept back. Calculations have suggested that, for every $1 \%$ increase in the cirrus clouds, there is a $0.2^{\circ} \mathrm{C}$ rise in the temperature of the Earth (Liou et al., 1990). In this way, air traffic contributes to global warming (the 'greenhouse' effect) on Earth (Grassl, 1990).

\section{Nitrogen Oxides: Ozone Producers and Destroyers}

In the lower layers of the atmosphere (troposphere), nitrogen oxides, together with hydrocarbons and ultraviolet light, form toxic ozone (Drummond et al., 1988; Wuebbles \& Kinnison, 1990). Air traffic emits a total of around three million metric tons of nitrogen oxides annually (1989 estimate), about 1 million metric tons of it being in the particularly sensitive layers of the atmosphere between 9,000 and 13,000 metres (Egli, 1990). From there they migrate (diffuse) gradually to both higher and lower levels.

In contrast to near ground-level, where the nitrogen oxides are washed out by rain within days, above 10,000 metres, for instance, they persist in the atmosphere for about a year (after 1 year, some 37\% of the nitrogen oxides are still there according to Fabian, 1990). Above about 12,000 metres, nitrogen oxides from aircraft contribute to the breakdown of ozone in the stratosphere (Rudloff, 1988; Johnston et al., 1989; Crutzen \& Brihl, 1990). There they react with water vapour to form nitric acid. This crystallizes at altitudes between 12,000 and 26,000 metres to form polar stratospheric clouds as soon as the temperature falls to about $-80^{\circ} \mathrm{C}$.

Surface-catalysed chemical reactions occur in these nitric acid-containing clouds. Starting from chlorofluorocarbons (CFCs), e.g. aerosol propellants, ozone is intensely destroyed via free chlorine. This occurs mainly with the aid of sunlight at the end of the Antarctic polar night. In this way the so-called 'ozone hole' arises (Arnold, 1988; Crutzen \& Müller, 1989). Moreover, the decrease in the ozone and the increase in carbon dioxide both lead to a cooling of the stratosphere and enhance the 'greenhouse' effect. In this way, critical temperatures of around $-80^{\circ} \mathrm{C}$ are to be found to an increasing extent even in the north, 
and the development of additional ozone holes is expected to be acute. The increasing ozone near ground-level provides no compensation, as $90 \%$ of the ozone is to be found in the stratosphere - without ozone in the stratosphere, life on Earth would scarcely be possible, as it filters out the destructive short-wave ultraviolet radiation.

\section{Carbon Dioxide and Other 'Greenhouse' etc. Pollutants}

Air traffic accounts for some 13\% (1988 figure) of carbon dioxide emissions from all forms of traffic worldwide, corresponding to the amount of fuel consumed (IEA-International Energy Agency, 1990). Climatologists estimate that the total increase in carbon dioxide is responsible for about half of the rise in temperature due to the 'greenhouse' effect.

Pollutants of lesser consequence are also produced by air traffic: these include 1 gram of sulphur dioxide per $\mathrm{kg}$ of kerosene (1.27 litres, totalling about 150,000 metric tons of $\mathrm{SO}_{2}$ annually world-wide), together with soot, carbon monoxide, and hydrocarbons. The last three effluents have been considerably reduced from the newer large engines, although at the expense of increased emission of nitrogen oxides. Furthermore, a problem that has not been solved, particularly over inhabited areas, is the deposition of fuel before risky landings, also referred to as fuel dumping. Kerosene in fact contains up to $20 \%$ of toxic aromatic substances, some of which can cause cancer.

\section{Constantly Increasing Fuel Consumption}

Flights over the seas and oceans, which make up $c$. $71 \%$ of the Earth's surface, and flights over the less-developed and developing countries, do not appear in any national statistics on fuel consumption and air pollution. The basis for any statement or assertion must therefore be provided by the amounts of fuel filled into aircraft tanks, as supplied by the International Energy Agency (IEA, 1990). The overall figures, supplied by IEA are as follows:

Consumption of Aircraft Fuel (in millions of metric tons)

$\begin{array}{lccccc} & 1983 & 1985 & 1987 & 1988 & (1990)^{*} \\ \text { USA } & 50.70 & 59.38 & 65.27 & 67.97 & (74.3)^{*} \\ \text { World-wide } & & 141.3 & 153.2 & 160.4 & (176)^{*}\end{array}$

* Figures predicted for 1990 are based on the forecast of the US Federal Aviation Administration.

In 1988, world-wide consumption of fuel (gasoline, diesel, and kerosene) was 1,206 million metric tons. The amounts of fuel can be used to calculate the amounts of pollutants, using the average emission index. In this respect, it is interesting to compare nitrogen oxides with other sources of pollution (Swiss BUWAL figures in grams of nitrogen oxides per $\mathrm{kg}$ of fuel or oil):

Air traffic

Road traffic

without catalytic converter with catalytic converter

Oil heating

about 20

about 44

about 4

about $1-3$

It should be noted that, for physical reasons, catalytic converters cannot be used in jet engines. The statistics put out by the airlines mostly refer only to emissions up to an altitude of 915 metres (LTO cycle), and disregard the emissions of water and carbon dioxide. For this reason, most of the emission figures in the literature are much too low.

\section{Energy-intensive Air Traffic}

.Air traffic accounts for some $13 \%$ of the world-wide consumption of all fuels (1988 figure), although for only less than $1 \%$ of world-wide transportation (of persons and freight). Compared with railways, air traffic consumes about 10 times as much energy per person per $\mathrm{km}$, and about 100 times as much energy per ton of freight per $\mathrm{km}$. About 60 litres of kerosene are consumed per person for every hour of flying time. For intercontinental flights, the kerosene needed weighs about 3 times as much as the freight and passengers!

\section{What Ought to be Done?}

To limit the harmful effect on the climate, it is imperative to limit air traffic. It could take years before this is realized and accepted throughout the world, and before restrictive measures show an effect. Nevertheless, it would in the meantime be political and economic nonsense to expand air traffic still further. The following measures need to be taken urgently:

- Increase the price of kerosene air fuel by making the fuel used internationally no longer exempt from tax and duty. In the period 1986-88, kerosene has cost only 16 US cents per litre.

- Stop all forms of state subsidies or measures to promote air traffic.

- Ban all passenger flights of less than $1,000 \mathrm{~km}$.

— Limit all other flights to altitudes below 9,000 metres.

- It is to be hoped that disarmament negotiations will also drastically reduce military flights. Such flights use up about $24 \%$ of air fuel today.

- Supersonic flights (e.g. of Concorde aircraft) are extremely harmful and as such are unacceptable. Projects for even faster aircraft that fly even higher should be stopped (e.g. projects in the USA, Great Britain, Japan, France, and Germany).

- Space flights should be reduced to an absolute minimum.

\section{CONCLUSIONS}

The total amount of fuel consumed, and especially that used by air traffic, makes a decisive contribution to the climatic changes that are threatening us (Grassl \& Klingholz, 1990). Besides road traffic and the excessively high consumption of energy in general, air traffic should be urgently restricted too. For this, discerning parliamentarians and government authorities are needed who are prepared to take action.

\section{REFERENCES}

ARNOLD, F. (1988). Neue Erkenntnisse zur Entstehung des Ozonlochs. Physikalische Blätter, 44, p. 404.

Crutzen, P.J. \& BRühl, CH. (1990). The atmospheric chemical effects of aircraft operations. Pp. 96-106 in Air Traffic and the Environment (Ed. U. SchumanN). Springer Verlag, Berlin \& Heidelberg, Germany: 170 pp., illustr.

Crutzen, P.J. \& Müller, M. (1989). Das Ende des blauen Planeten? Verlag Beck, München, Germany: 271 pp., illustr.

Drummond, J.W., Ehhalt, D.H. \& Volz, A. (1988). Measurements of nitric oxide between $0-12 \mathrm{~km}$ altitude and $67^{\circ} \mathrm{N}$ to $60^{\circ} \mathrm{S}$ latitude obtained during STRATOZ III. Journal of Geophys. Research, 93, pp. 15,831-49, illustr.

EGLI, R.A. (1990). Nitrogen oxide emissions from air traffic. Chimia, 44, pp. 369-71.

FABIAN, P. (1990). Behaviour of atmospheric aircraft emissions: Conversion processes. Pp. 9-18 in Ecological Impacts of Aircraft Emissions. Tutzinger Materialie No. 66, Evang. Akademie, D-8132 Tutzing, Germany: 59 pp., illustr.

[concluded on page 44] 


\section{[continued from page 32]}

NeHRing, A. (1902). Mustela fonia syriaca from Jordan. Sitzber Ges. Naturf. Fr. Berlin, p. 145.

Nelson, B. (1973). Azraq Desert Oasis. Allen Lane, London, England, UK: xix +436 pp., illustr.

PAZ, U. (1982). The fauna of the Holy Land at the end of the Ottoman period. Isr. Land and Nat. Spring, 1982, pp. 104-10.

Perkins, D., jun. (1966). The fauna from the Madamagh and the Beidha. Palestine Exploration Quarterly, Five Seasons at the Beidha, Appendix B, pp. 66-7.

PERKINS, D., jun. (1968). The Pleistocene fauna from the Yabrud Rockshelters. Annales Archeologiques Arabe Syrienne, 18, pp. 123-30.

PonTICELLI, S.C. (1979). Testimonianze neolitiche nel deserto della Giordana meridimale Estratto da'. Studi Per Ecologia del Quaternario [not available for checking].

PoR, F. (1987). The Levantine landbridge: historical and present patterns. Pp. 23-8 in Proceeding of the Symposium on the Fauna and Zoogeography of the Middle East, Mainz 1985 (Eds F. KRUPP, W. SCHNEIDER \& R. KINZELbaCH). Beihefte Zum TAVO A 28: pp. 23-8.

QUMSIYEH, M.B. (1980). New records of bats from Jordan. Saugetierk. Mitt., 28, pp. 36-9.

QumsiYeH, M.B. (1985). The Bats of Egypt. Special Publ., Museum Texas Tech. Univ., No. 23, 102 pp., illustr.

Qumsiyeh, M.B., SchlitTer, D. A. \& Disi, A.M. (1986). New records and karyotypes of small mammals from Jordan. Sonderdruck aus Z.F. Saugetierk Bed,, 51, pp. 139-46.

SEARIGHT, A. (1987). Some records of mammals from north-eastern Jordan. Proceedings of the Symposium on the Fauna and Zoogeography of the Middle East Mainz, 1985 (Eds F. KRUPP, W. SCHNEIDER, \& R. KINZELbACH). Beihefte Zum TAVO A 28 , pp. 311-7.

Short Communications and Reports [continued from page 74]

Grassl, H. (1989). Wolkenbilding und Flugzeuge. Pp. 69-107 and 166-67 in Unheil über unseren Köpfen? (Ed. M. PFEIFFER \& M FISCHER). Quell-Verlag, Stuttgart, Germany: 239 pp., illustr.

Grassl, H. (1990). Possible climatic effects of contrails and additional water vapor. Pp. 124-37 in Air Traffic and the Environment (Ed. U. SchumanN), Springer Verlag, Berlin \& Heidelberg, Germany: 170 pp., illustr.

Grassl, H. \& Klingholz, R. (1990). Wir Klimamacher. S. FischerVerlag, Frankfurt, Germany: 296 pp., illustr.

IEA (International Energy Agency) (1990). Oil and Gas Information 1987-1989. IEA, 2 Rue André Pascal, 75775 Paris, Cedex 16 France: 602 pp., illustr.

JOHNSTON, H.S., KinNisOn, D.E. \& WuEBbLES, D.J. (1989), Nitrogen oxide from high-altitude aircraft, an update of potential effects on ozone. Journal of Geophys. Research, 94, pp. 16,351-63, illustr.
TALBOT, L.M. (1960). A look at threatened species: A report on some animals of the Middle East and Southern Asia which are threatened with extermination. Oryx, 5, pp. 153-293.

Thomas, O. (1892). On Gerbillus calurus from Sinai and Meriones tristami from Palestine. Ann. Mag. Nat. Hist., 6(9), pp. 76-148.

Thомаs, O. (1917). A new vole from Palestine [Microtus philistinus, a form of Gunther's Vole]. Ann. Mag. Nat. Hist., 19(8), pp. 450-1.

Thomas, O. $(1919 a)$. The White-toothed shrew of Palestine. Ann. Mag. Nat. Hist., 9(3), p. 32 [describes Crocidura russula judaica].

Thomas, O. (1919b). Two new gerbils from Sinai. Ann. Mag. Nat. Hist., 9(3), pp. 559-60.

Thomas, O. (1922a). The forms of Jaculus jaculus in Egypt and Syria. Ann. Mag. Nat. Hist., 9(9), pp. 295-7.

Thомаs, O. (1922b). A new jird (Meriones) from Palestine. Ann. Mag. Nat. Hist., 9(10), pp. 552-3.

TOQUAN, F. (1979). Al-Haar: A Research in the Ummayad Palaces in The Badia. Dar Al-Shab Press and Ministry of Culture and Youth, Amman, Jordan: 551 pp., illustr.

Tristram, H.B. (1866). Report on the mammals of Palestine. Proc. Zool. Soc. London, 1866, pp. 84-93.

Tristram, H.B. (1884). The Survey of Western Palestine, The Fauna and Flora of Palestine. Pub, by the Committee of the Palestine Exploration Fund, London, England, UK: pp. 1-30.

VAUfREY, R. (1951). Mammiferes. Pp. 198-217 in Le Paleolithique Mesolithique du désert de Judée (Ed. R. Neuville). Archives Institute Paleontologie Humaine, 24.

WASSIF, K. (1954). On a collection of the mammals from northern Sinai. Bull. Inst. Desert d'Egypt, 3(1), pp. 107-18.

ZAYADINE, F. (1977). The Frescos of Qusier Amra. Department of Antiquities of Jordan, Amman, Jordan: 14 pp. +21 figs.

KaVANaugh, M. (1988). New Estimates of $\mathrm{NO}_{x}$ from Aircraft: 1975-2025. 81st Annual Meeting of APCA, the Association Dedicated to Air Pollution Control and Hazardous Waste Management, Pittsburgh, USA: 1-15 pp., illustr.

LIOU, K.N., OU, S.C. \& KoENIG, G. (1990). An investigation of the climatic effect of contrail cirrus. Pp. 154-69, in Air Traffic and the Environment (Ed. U. SCHUMANN). Springer Verlag, Berlin \& Heidelberg, Germany: 170 pp., illustr.

RudLOFF, H. vON (1988). Luft- und Raumfahrt als Ozonkiller Raum und Zeit, 37, pp. 22-36, illustr.

Wuebbles, D.J. \& KinNison, D.E. (1990). Sensitivity of stratospheric ozone to present and possible future aircraft emissions. Pp. 107-23 in Air Traffic and the Environment (Ed. U. SCHUMANN). Springer Verlag, Berlin \& Heidelberg, Germany: $170 \mathrm{pp}$. , illustr.

ROBERT A. EGLI

Chemist and Air Pollution Consultant Etzelstrasse 15

CH-8200 Schaffhausen

Switzerland.

Notes, News \& Comments [continued from page 80]

\section{Convention on Damage Caused to the Environment}

A convention on damage resulting from activities that prove dangerous to the environment is being prepared by the Council of Europe, in response to the need to propose measures to compensate victims of damage to the environment. To date, such problems have received scant attention at any international level - with the exception of specific issues such as nuclear energy or the transport of goods.

In addition to providing for suitable compensation, the Convention will offer the bases of means to prevent environmental damage and of those to rehabilitate impaired sites. Provision will also be made for access to pertinent information - particularly information that held by public authorities or industrial operators.

DIRECTORATE OF LEGAL AFFAIRS
Council of Europe
Boite Postale 431 R6
F-67006 Strasbourg Cedex
France.

Council of Europe

F-67006 Strasbourg Cedex

France. 